\title{
The Impact of COVID-19 on Medical Practice: A Nationwide Survey of Dermatologists and Healthcare Providers in Iraq
}

Mohammed Shanshal ${ }^{1,{ }^{*}}$, Hayder Saad Ahmed ${ }^{2, \wedge}$, Hayder Asfoor ${ }^{3, *}$, Raad Ibrahim Salih $^{2, \wedge}$, Shehab Ahmed $\mathrm{Ali}^{4, \wedge}$, Yusif k. Aldabouni ${ }^{1, \wedge}$

${ }^{1}$ Baghdad Teaching Hospital, Department of Dermatology and Venereology, ${ }^{2}$ University of Tikrit, College of Medicine, Department of Dermatology and Venereology, ${ }^{3}$ University of Kerbala, College of Medicine, Department of Medicine, ${ }^{4} \mathrm{Al}$ - iskandria Hospital, Department of Dermatology and Venereology

* Specialist dermatologist, MBChB, FABMS - Dermatology

^Specialist dermatologist, MBChB, FIBMS - Dermatology

Corresponding author:

Mohammed Shanshal, MBChB, FABMS - Dermatology

Specialist Dermatologist at Baghdad Teaching Hospital, Department of Dermatology and Venereology

Email: doctor.dermatology30@yahoo.com

ORCID Id: https://orcid.org/0000-0003-2877-5919

Word count: 2227

Abstract word count: 199

Highlights: 51

Number of figures: 5

Number of tables: 5

Number of references: 24

Conflicts of interest: None

Funding sources: None

Patient privacy and ethical use of images:

The patients in this manuscript have given written informed consent for publication of their case details, including the use of images.

key words:

PPE-related dermatoses, COVID-19 pandemic, COVID-19 and dermatology, COVID19 cutaneous manifestations, Telemedicine 


\section{Abstract}

The COVID-19 pandemic has dramatically changed medical practice worldwide. It posed a significant impact on different health services, including dermatology. A Cross-sectional observational study of 200 healthcare providers and 100 dermatologists (survey 1 and 2, respectively) were conducted to determine the prevalence of occupational skin diseases among healthcare providers working amid the pandemic, and to demonstrate the outbreak's impact on dermatology practice.

Most healthcare providers (83\%) reported hygiene-related hand dermatitis. The rates of PPE- related dermatoses were estimated to be $73 \%$, including pressure injuries (51.9\%), acne (33.1\%), non-gloves contact dermatitis (29.9\%), nonspecific eruption (17.5\%), urticaria (9.1\%) and skin infections (3.2\%). The emerging COVID19-related cutaneous manifestations were recognized by $20 \%$ of surveyed dermatologists, including maculopapular eruption (41.67\%), urticaria (37.50\%), chilblain (25\%) and vasculitis (16.67). Telemedicine was provided by $73 \%$ of the dermatologists, and $89 \%$ reported minimal use of immunosuppressive drugs amid the pandemic. 
An ongoing outbreak of coronavirus disease 2019 (COVID-19) caused by SARSCoV-

2, started in December 2019. It was first identified in Wuhan, China. The virus then propagated and began to hit other regions around the world until it was declared a global pandemic by the World Health Organization (WHO) on March 11, $2020^{(1)}$.

The emerging COVID-19 virus is phylogenetically linked to viruses that cause severe acute respiratory syndrome (SARS) and Middle East respiratory syndrome (MERS). COVID-19 creates variable degrees of illness, ranging from fever, cough, dyspnea, fatigue, and diarrhea to critical cases of severe acute respiratory distress syndrome ${ }^{(2)}$.

The COVID-19 pandemic has brought the world to a standstill and placed considerable challenges on healthcare workers, including dermatologists. Telemedicine has gained particular importance, where many of the dermatologic consultations were transitioned into teledermatology services. The current outbreak has led to the ongoing emergence of personal protective equipment (PPE)- related dermatoses and hygiene-related hand dermatitis, particularly among healthcare providers. In addition, due to a shortage of vaccination programs imposed by the COVID-19 lockdown, there is a significant risk for other infectious disease outbreaks, including measles. 


\section{Objectives and methods}

A cross-sectional observational study involving two online surveys were conducted for data collection. The purpose of using two questionnaires is twofold:

1. to comprehensively examine the effect of COVID-19 on different aspects of medical practice

2. to concentrate on the virus effect on dermatologic practice.

A 5-item electronic survey was created and sent to 276 randomly selected healthcare providers working in the emergency departments, inpatient wards, and outpatient clinics of the major hospitals in Iraq. The survey assessed the frequency of occupational skin diseases due to hygienic work practices and PPE use among healthcare providers working during the current pandemic. The participants were asked about their gender, age, and the frequency of hygienerelated

hand dermatitis and skin complications related to PPE use.

For survey 2, a 12-item electronic questionnaire was sent to 156 randomly selected dermatologists practicing within the COVID-19 era. The dermatologists were asked about the impact of the current outbreak on various aspects of dermatology practice, including the provided medical services, infection control methods, disease epidemiology, and the currently recommended medical and 
medRxiv preprint doi: https://doi.org/10.1101/2020.07.26.20156380; this version posted November 28, 2020. The copyright holder for this preprint (which was not certified by peer review) is the author/funder, who has granted medRxiv a license to display the preprint in perpetuity.

surgical management.

\section{Results}

In the first survey, a total of 200 responses were collected from healthcare

providers working amid the COVID-19 pandemic with a response rate of $(72.46 \%)$.

The results of the first survey are summarized in table 1 and 2 .

\section{Table 1:}

Occupational skin diseases among health care providers working amid COVID-19

\begin{tabular}{|l|c|l|l|}
\hline & Male $\mathbf{n}(\%)$ & Female $\mathbf{n}(\%)$ & Total n (\%) \\
\hline Response rate & $72(36 \%)$ & $128(64 \%)$ & $200(72.46 \%)$ \\
\hline Hygiene- related & & $123(74 \%)$ & $166(83 \%)$ \\
\hline PPE-related & $43(25.9 \%)$ & $111(75.5 \%)$ & $147(73.5 \%)$ \\
\hline
\end{tabular}




\section{Table 2:}

Types and frequency of PPE-related dermatoses

\begin{tabular}{|l|c|c|c|}
\hline & Male $\mathbf{n}(\%)$ & Female $\mathbf{n}(\%)$ & Total $\mathbf{n}(\%)$ \\
\hline Pressure injuries & $14(17.5)$ & $66(82.5 \%)$ & $80(51.9 \%)$ \\
\hline Acne & $8(15.68)$ & $43(84.3 \%)$ & $51(33.1 \%)$ \\
\hline Non-gloves CD & $11(24 \%)$ & $35(76 \%)$ & $46(29.9 \%)$ \\
\hline Non-specific rash & $5(18.5 \%)$ & $22(81.5 \%)$ & $27(17.5 \%)$ \\
\hline Urticaria & $3(21.42 \%)$ & $11(78.57)$ & $14(9.1 \%)$ \\
\hline Skin infections & $3(60 \%)$ & $2(40 \%)$ & $5(3.2 \%)$ \\
\hline
\end{tabular}

In the second survey, the questionnaire was completed by 100 practicing

dermatologists, providing a $64 \%$ response rate. The survey questions and results are illustrated in Tables 3, 4, and 5.

Table 3

Impact of COVID-19 on dermatology practice: Survey questions and results

\begin{tabular}{|l|l|l|}
\hline & Yes $\mathbf{n = ( \% )}$ & No $\mathbf{n = ~ ( \% ) ~}$ \\
\hline $\begin{array}{l}\text { Do you continue to perform } \\
\text { dermatological procedures and } \\
\text { biopsies? }\end{array}$ & $\begin{array}{l}71 \text { (yes, but at limited capacity) } \\
16 \text { (yes, as before the } \\
\text { outbreak) }\end{array}$ & 13 \\
\hline $\begin{array}{l}\text { Are you still using } \\
\text { immunosuppressive to treat } \\
\text { skin conditions? }\end{array}$ & $\begin{array}{l}68 \text { (yes, but only for limited } \\
\text { cases when highly indicated) } \\
11 \text { (yes, as before the outbreak) }\end{array}$ & 21 \\
\hline
\end{tabular}




\begin{tabular}{|l|l|l|}
\hline $\begin{array}{l}\text { Do you diagnose one of the } \\
\text { COVID-19 skin manifestations? }\end{array}$ & 20 & 80 \\
\hline $\begin{array}{l}\text { Due to COVID-19 related } \\
\text { psychological upset, do you } \\
\text { notice an increase in relapse } \\
\text { rate of some chronic skin } \\
\text { diseases? }\end{array}$ & 51 & 49 \\
\hline $\begin{array}{l}\text { Do you try to switch } \\
\text { immunosuppressive to more } \\
\text { conservative options like } \\
\text { topical agents/ phototherapy? }\end{array}$ & 81 & 19 \\
\hline $\begin{array}{l}\text { Do you get COVID-19 infection } \\
\text { during your work? } \\
\text { (PCR confirmed case only) }\end{array}$ & 25 & 75 \\
\hline $\begin{array}{l}\text { Do you provide online/ phone } \\
\text { consultations } \\
\text { (teledermatology)? }\end{array}$ & 72 & 81 \\
\hline $\begin{array}{l}\text { Did you work at the respiratory } \\
\text { triage or any other CoVID-19 } \\
\text { related unit? }\end{array}$ & 19 & 28 \\
\hline $\begin{array}{l}\text { Did you diagnose a case of } \\
\text { measles during the current } \\
\text { pandemic? }\end{array}$ & 14 & 86 \\
\hline
\end{tabular}




\section{Table 4}

Cutaneous manifestations of COVID-19 diagnosed by dermatologists

\begin{tabular}{|l|c|c|}
\hline & $\mathbf{n}$ & $\%$ \\
\hline $\begin{array}{l}\text { Erythematous maculopapular } \\
\text { rash }\end{array}$ & 10 & $41.67 \%$ \\
\hline Urticaria & 9 & $37.50 \%$ \\
\hline Chilblain & 6 & $25 \%$ \\
\hline Vasculitis & 4 & $16.67 \%$ \\
\hline
\end{tabular}

\section{Table 5}

Dermatoses aggravated by COVID-19 related psychological stress

\begin{tabular}{|l|c|c|}
\hline & $\mathbf{n}$ & \% \\
\hline Psoriasis & 33 & $64.70 \%$ \\
\hline Atopic dermatitis & 30 & $58.82 \%$ \\
\hline Rosacea & 9 & $17.64 \%$ \\
\hline Vitiligo & 5 & $9.80 \%$ \\
\hline alopecia areata & 3 & $5.88 \%$ \\
\hline
\end{tabular}




\section{Discussion}

\section{Impact of COVID-19 on medical services}

We have reviewed the impact of COVID-19 pandemic on the practice of

dermatology in Iraq. Although the population of Iraq exceeded 40 million in 2020,

based on the latest United Nation data ${ }^{(3)}$, available statistics indicate that the

number of physicians is 7.08 per 10,000 populations which is extremely low when

compared to developed countries (4).

On February 24, 2020, Iraq announced the first confirmed case of SARS-CoV-2

infection. Since then, the spread of COVID-19 has increased. exponentially. By

early September, about 260,370 confirmed cases and 7,512 deaths had been

reported in Iraq ${ }^{(5)}$.

The COVID-19 pandemic has targeted every single aspect of medical practice,

including dermatology. As Baghdad became the epicenter of the COVID-19

pandemic in mid-March, most dermatology clinics were closed or continued to

operate at a minimal capacity. The objective was to provide essential medical care 
medRxiv preprint doi: https://doi.org/10.1101/2020.07.26.20156380; this version posted November 28, 2020. The copyright holder for this preprint (which was not certified by peer review) is the author/funder, who has granted medRxiv a license to display the preprint in perpetuity. All rights reserved. No reuse allowed without permission.

for emergency cases, such as Stevens-Johnson syndrome/toxic epidermal necrolysis, erythroderma, acute angioedema, and lesions worrisome for skin cancer.

With the acute shortage of PPE, medical practitioners clenched their teeth with each patient, wondering if they had been exposed to the virus already. COVID-19 patients may present with a wide range of dermatologic manifestations with or without typical respiratory signs ${ }^{(6)}(7)$.

Of the 100 dermatologists involved in the survey, 20\% reported diagnosing one or more COVID-19 related skin manifestations. These have included the most commonly diagnosed diseases: erythematous maculopapular eruption (41.67\%), urticaria (37.50\%), chilblains (25\%), and vasculitis (16.67\%) (Figure 1). 

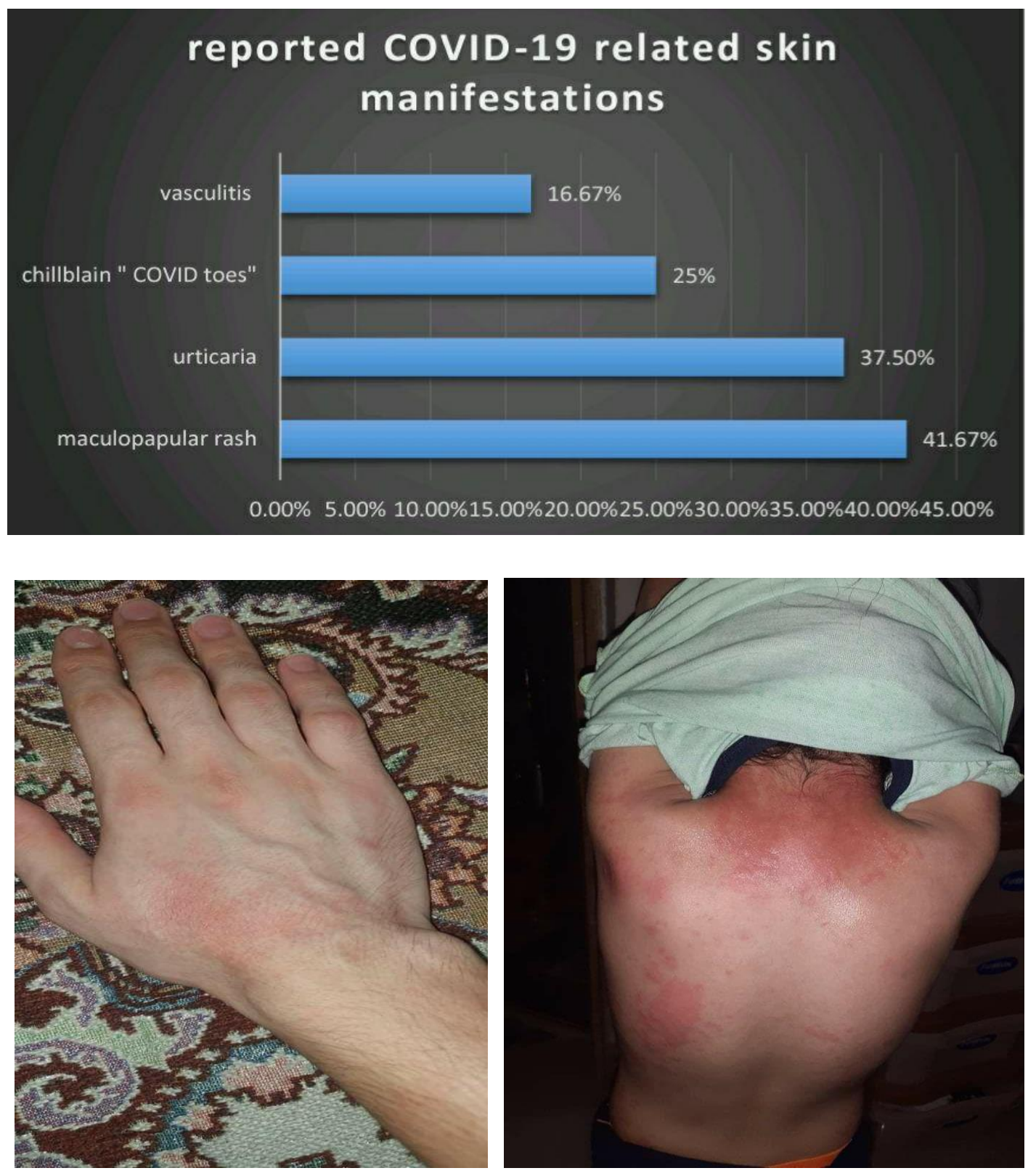

Figure 1: COVID-19 related cutaneous manifestations

(A) The approximate frequency of diagnosed COVID-19 related skin manifestations reported by dermatologists. (B) 25 years old male with erythematous maculopapular eruption involving the extremities (C) 12 years old girl with generalized urticarial eruption. 


\section{Impact of COVID-19 on infection control}

The dermatology team tried to reduce face-to-face consultations in both public hospitals and private practice clinics, limiting them to emergency patients. Nonemergent presentations, including melasma, acne, vitiligo, and stable psoriasis, were diverted to telemedicine platforms to avoid the unwarranted risk of spreading infection. Despite these measures, about 25 dermatologists

contracted COVID-19 during routine patient care.

The survey revealed that during the outbreak, $72 \%$ of practicing dermatologists provided teledermatology consultations through telephone and/or online social network applications. Because dermatology diagnosis depends primarily on visual characteristics, dermatologists had already been leaders in providing telemedicine services even before the crisis, leading to greater success with this experience.

In order to reduce the risk of infection spread while attending dermatology clinics, several measures have been implemented including stressing commitment to social distancing and wearing a mask, the pre-examination measurement of the 
medRxiv preprint doi: https://doi.org/10.1101/2020.07.26.20156380; this version posted November 28, 2020. The copyright holder for this preprint (which was not certified by peer review) is the author/funder, who has granted medRxiv a license to display the preprint in perpetuity. All rights reserved. No reuse allowed without permission.

patient's temperature, and exclusion of the respiratory symptoms at the hospital entrance respiratory triage unit, in addition to the meticulous disinfection of equipment ${ }^{(8)}$ (Figure2).

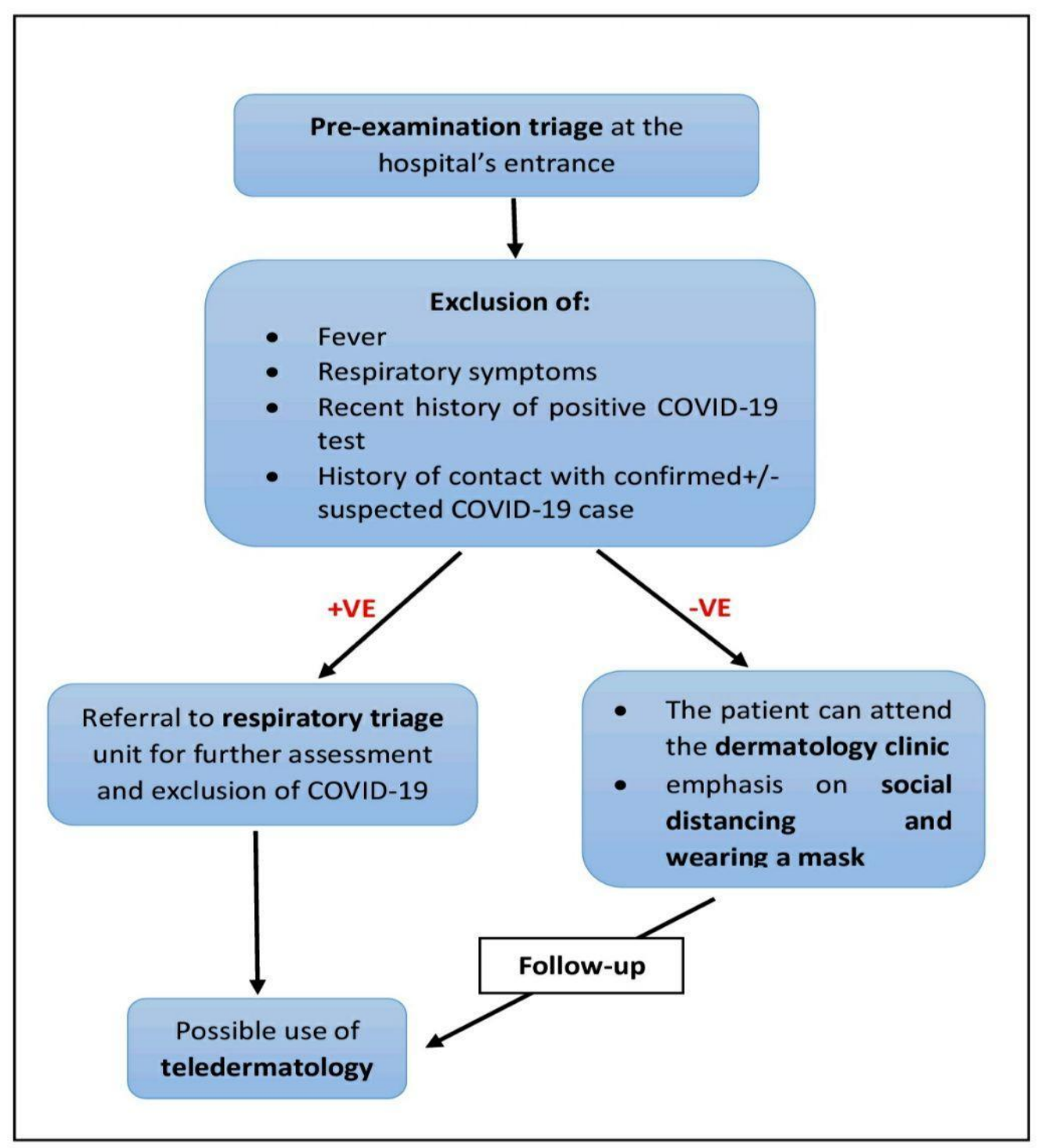

Figure 2: COVID-19 pre-examination triage steps

Flowchart represents the pre-examination triage to decrease the risk of infection spread while attending the dermatology clinic and utilizing teledermatology for initial +/- follow-up assessment. 


\section{Impact of COVID-19 on skin disease epidemiology}

\section{Hand dermatitis}

Due to frequent handwashing, prolonged use of gloves, and overuse of

disinfectants, the incidence of hand dermatitis among healthcare staff and the

general population has dramatically increased (Figure 3).

In this survey, hand dermatitis was reported in $83 \%$ of healthcare providers

working during the current pandemic. Another study reported a comparable

result of gloves-related hand dermatitis (88.5\%) among healthcare providers

working in Hubei Province hospitals amid the outbreak ${ }^{(9)}$. A pre-outbreak

epidemiologic study in mainland China found the frequency of hand dermatitis to

range from $14.3 \%$ to $23.8 \%$ across hospital departments, far from those recorded

during the COVID-19 outbreak ${ }^{(10)}$.

Several measures can be used to decrease the incidence of hand dermatitis,

including the use of mild soaps (syndets) that are equally effective in preventing

the viral spread and frequent use of moisturizers and physical barriers, especially 
medRxiv preprint doi: https://doi.org/10.1101/2020.07.26.20156380; this version posted November 28, 2020. The copyright holder for this preprint (which was not certified by peer review) is the author/funder, who has granted medRxiv a license to display the preprint in perpetuity. All rights reserved. No reuse allowed without permission.

after handwashing to protect the skin and decrease irritation. Depending on the severity of the lesions, established hand dermatitis should be treated with emollients and/or topical steroids (11).
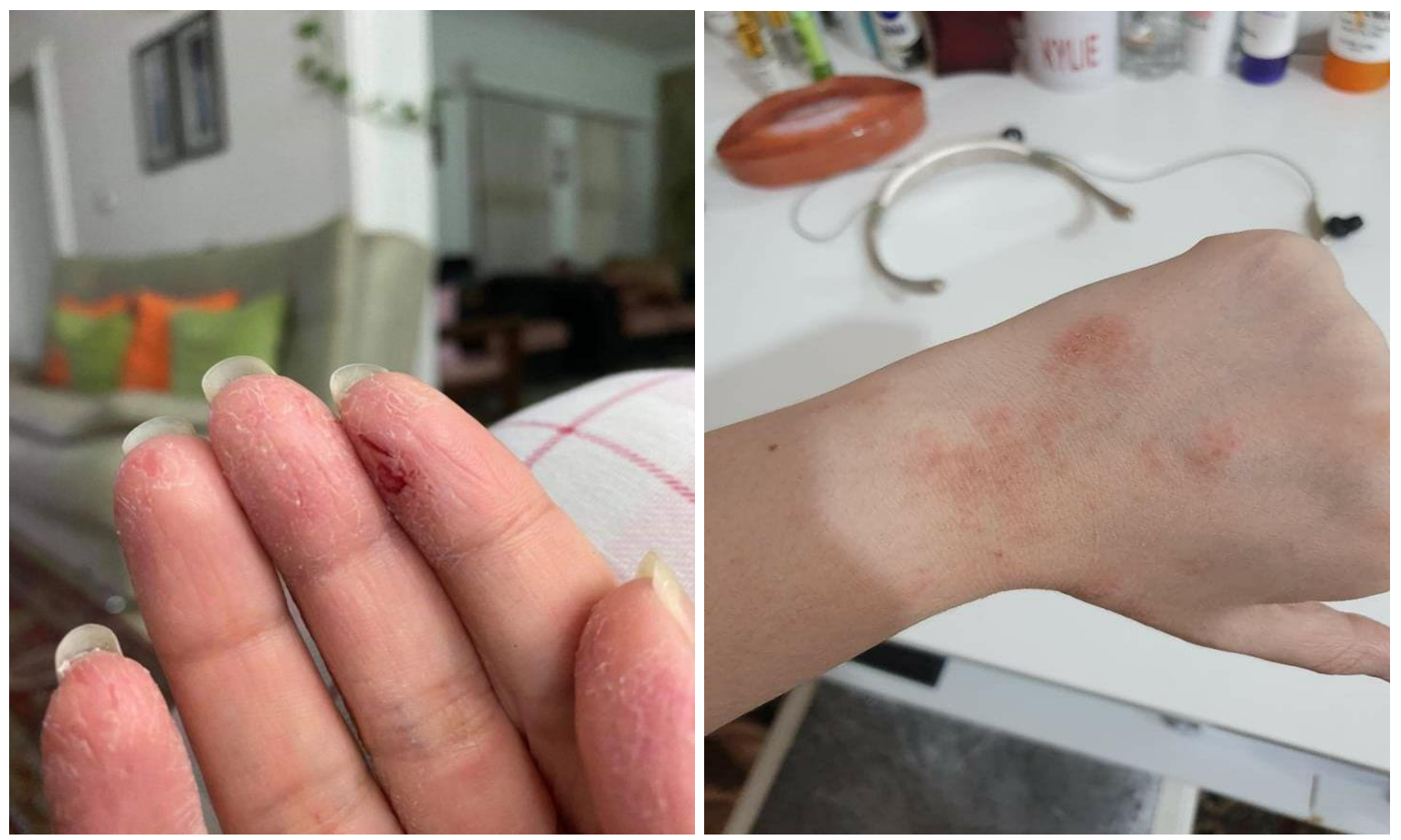

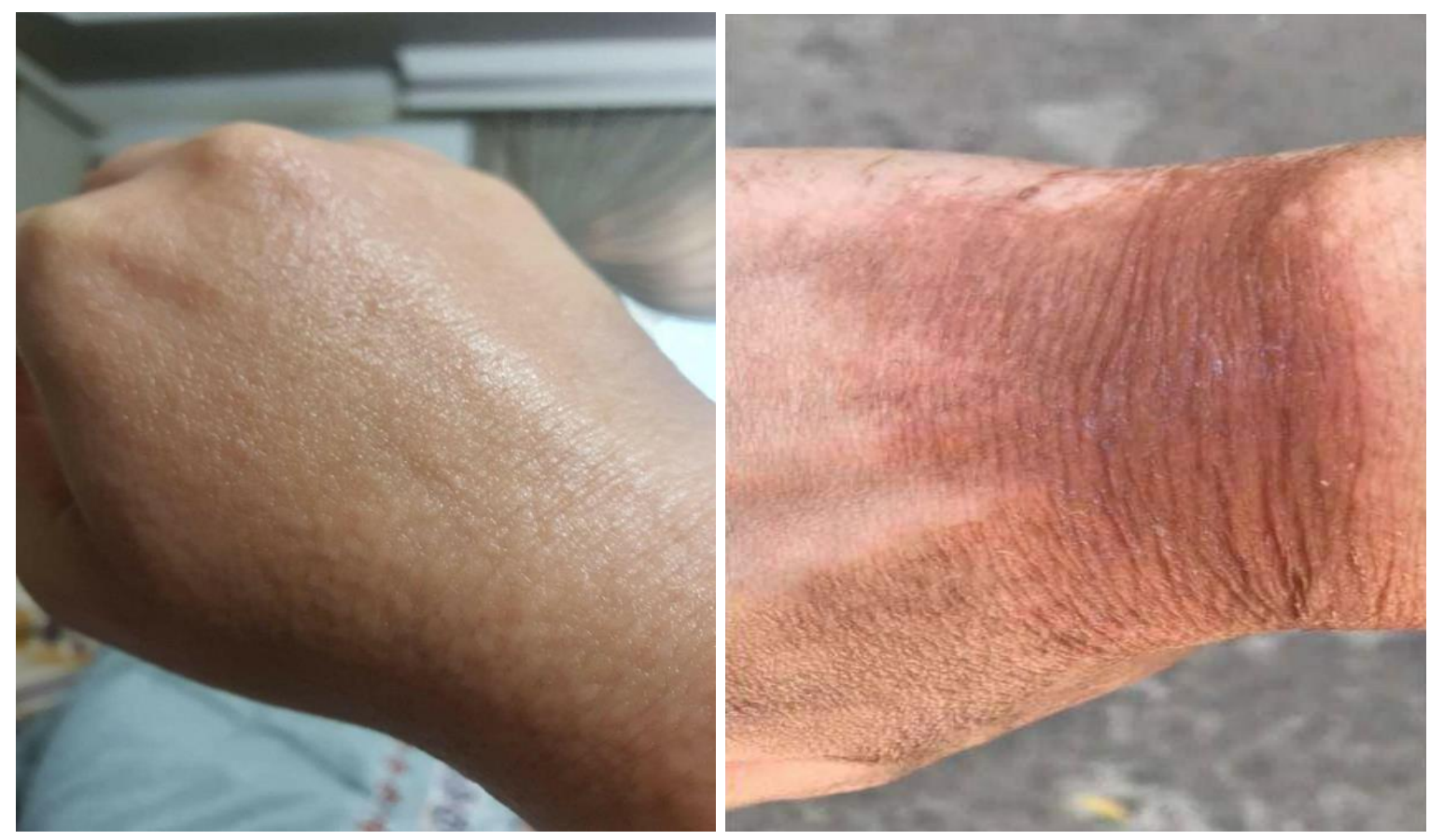

Figure 3: Hygiene-related hand dermatitis

(A) (B) Eczematous contact dermatitis (C) Papular contact dermatitis (D) Postinflammatory hyperpigmentation following severe disinfectants-related dermatitis

\section{Personal protective equipment (PPE)-related dermatoses}

Prolonged contact with PPE such as masks, protective gowns, face shields, and

goggles has led to an unprecedented emergence of PPE-related dermatoses

among healthcare providers working amidst the current pandemic. PPE-induced

skin injuries are attributed to mechanical friction, long-term occlusion, maceration, and allergic contact reactions ${ }^{(12)}$. 
dermatoses. Of these, 111 (75.5\%) occurred in women and $36(24.9 \%)$ in men.

The median age was 31 years (range $24-47$ years; standard deviation 4.94 years).

The frequency of PPE-related dermatosis reported in this survey includes:

pressure injuries (51.9\%), acne (33.1\%), non-gloves contact dermatitis (29.9\%), nonspecific dermatitis and itching (17.5\%), urticaria (9.1\%), and skin infections (3.2\%) (Figure 4). Folliculitis can occur at the site of skin friction, and the inflamed follicles may become infected with bacteria, especially Staphylococcus aureus.

Friction caused by surgical masks can also trigger reactivation of the Herpes simplex virus.

The frequency of PPE-related cutaneous complications among healthcare workers in the Hubei Province during the COVID-19 era included adverse skin reactions associated with the prolonged wearing of PPE, including N95 mask, latex glove, and protective clothing, were $95.1 \%, 88.5 \%$ and $60.7 \%$, respectively ${ }^{(8)}$.

During the SARS outbreak, the prevalence of PPE-related dermatosis among Singapore health care workers included the findings that $35.5 \%$ of the staff who 
used masks regularly developed acne (59.6\%), facial itching (51.4\%), and

dermatitis (35.8\%), while $21.4 \%$ who used gloves regularly developed adverse skin

reactions, including dry skin (73.4\%), itching (56.3\%), and dermatitis (37.5\%) ${ }^{(13)}$.

In an analysis of incident case reports from UK dermatologists, non-glove PPE related dermatoses between 1993 and 2013 revealed that $15.5 \%$ of the affected patients were health and social workers ${ }^{(14)}$.

General measures to reduce skin damage associated with the PPE include wearing suitable PPE, avoiding prolonged use wherever possible, and working in a cooler environment. In the areas of maximum tension, dressings can be applied to the skin to redistribute pressure and reduce friction. Frequent use of moisturizers is advisable to protect and repair the skin barrier, and adequate cleansing is necessary to prevent secondary infections ${ }^{(15)}$. Mild pressure injuries with intact epidermis usually heal spontaneously without intervention. Small bullae can be kept intact, while larger ones can be aspirated to 
medRxiv preprint doi: https://doi.org/10.1101/2020.07.26.20156380; this version posted November 28, 2020. The copyright holder for this preprint (which was not certified by peer review) is the author/funder, who has granted medRxiv a license to display the preprint in perpetuity. All rights reserved. No reuse allowed without permission.

ease the associated pressure. Eczematous lesions are treated with moisturizers and/or topical steroids, depending on the severity of the lesions. Antihistamines may be used for associated pruritus. For resistant cases, a patch test may be necessary to identify the allergen involved. Mask-related frictional acne can be treated with topical benzoyl peroxide, retinoids, and antimicrobials, similar to acne vulgaris ${ }^{(16)}$.
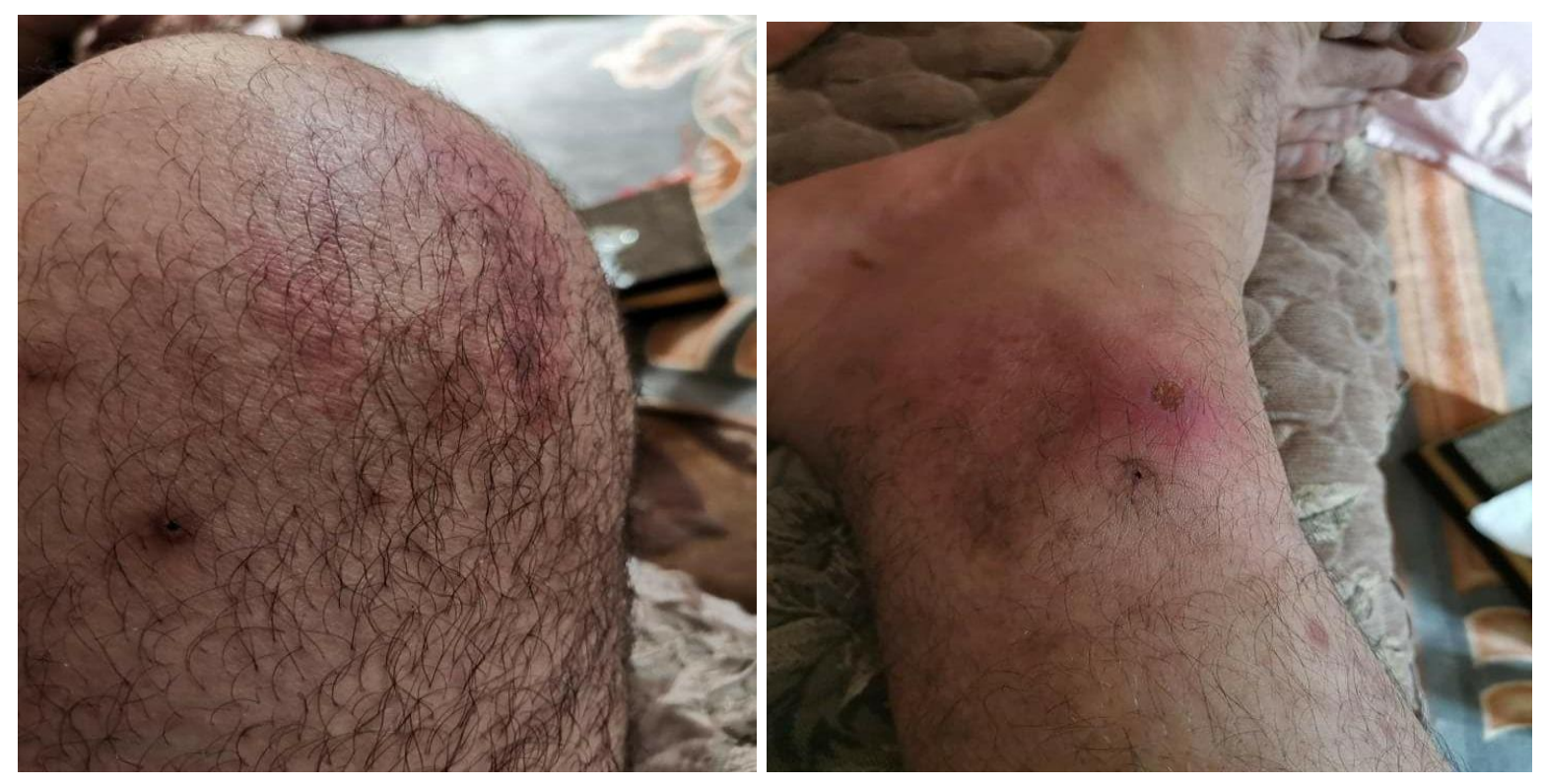

Figure 4: Spectrum of PPE-related dermatosis among healthcare provides working in COVID-19 era

(A) Pressure marks and frictional acne (B) Mask -induced contact dermatitis (C) and (D) Folliculitis and herpes simplex reactivation triggered by surgical mask friction $(E)$ and (F) gown-related contact dermatitis and urticaria (G) Pressure injuries and nonspecific rash (H) mask-related frictional acne (I) Goggles-related nasal bridge dermatitis and hyperpigmentation. 


\section{Chronic skin disease relapse}

It is currently enigmatic how COVID-19 can affect those with chronic skin

conditions such as psoriasis and how it can affect these individuals' treatment.

The psychologic impact of the crisis, patients' reluctance to attend a clinic

appointment, limited use of immunosuppressive drugs, and shortage of drugs

lead to a perceptible increase in the rate of relapse and exacerbation of several

chronic skin diseases ${ }^{(17)}$. Relapse rates of psoriasis, atopic dermatitis, rosacea,

vitiligo, and alopecia areata were noticeably increased as observed by $64.70 \%$,

$58.82 \%, 17.64 \% 9.80 \%$, and $5.88 \%$ of dermatologists, respectively.

Patients should be strongly advised against stopping their medications without

consulting their physicians ${ }^{(18)}$. The importance of supporting patients with chronic

dermatologic conditions during the current crisis cannot be overemphasized.

\section{$>$ Preventable infectious diseases}

The WHO expressed great concern about the spread of previously controllable infectious diseases like measles. Derangement of immunization services caused 
by the ongoing COVID-19 pandemic is likely to further to decrease measles vaccination coverage by an additional $20 \%$, leaving the most susceptible children at risk for highly infectious disease outbreak ${ }^{(19)}$. About $14 \%$ of the surveyed dermatologists recorded new cases of measles amid the current pandemic; hence, health authorities are called to emphasize the importance of identifying and reaching children with missed vaccine doses to avoid an inevitable outbreak.

\section{Impact of COVID-19 on dermatologic treatments}

Several expert opinions have recommended restricting the use of

immunosuppressive agents during the current pandemic (20) (21). Most

dermatologists in the survey reported reduced use of non-biologic

immunosuppressants and limited their prescription to selected cases, particularly

when alternative options are exhausted, and only after COVID19 symptoms have been excluded. In this condition, the dose should be kept to

the lowest acceptable level that still adequately controls the disease.

Due to the uncertainty of whether biologics may place patients at a higher risk of 
COVID-19 or more dramatic disease course, the initiation of biologic therapy in the current crisis is unadvisable. Alternative therapeutic approaches, particularly in vulnerable patients, may be considered ${ }^{(22)}$. Patients already receiving scheduled biological therapy, who do not exhibit respiratory symptoms or test positive for COVID-19 may continue their treatment while underscoring the importance of COVID-19 preventive measures, like social distancing and selfquarantining ${ }^{(23)}$.

\section{Impact of COVID-19 on surgical dermatology}

Most of the non-essential dermatological procedures and biopsies were postponed to minimize the risk of spreading COVID-19 infection. Skin surgery was limited to a few undeferrable biopsies and high-risk skin cancer removal when the risk of delay exceeded the risk of exposure to the virus (Figure 5). Some hospitals have applied specific internal protocols to protect their patients and staff, including testing patients for COVID-19 before their scheduled surgeries and procedures, providing full PPE to all operating staff, and solicitous intraoperative environment sterilization and waste disposal (24). 

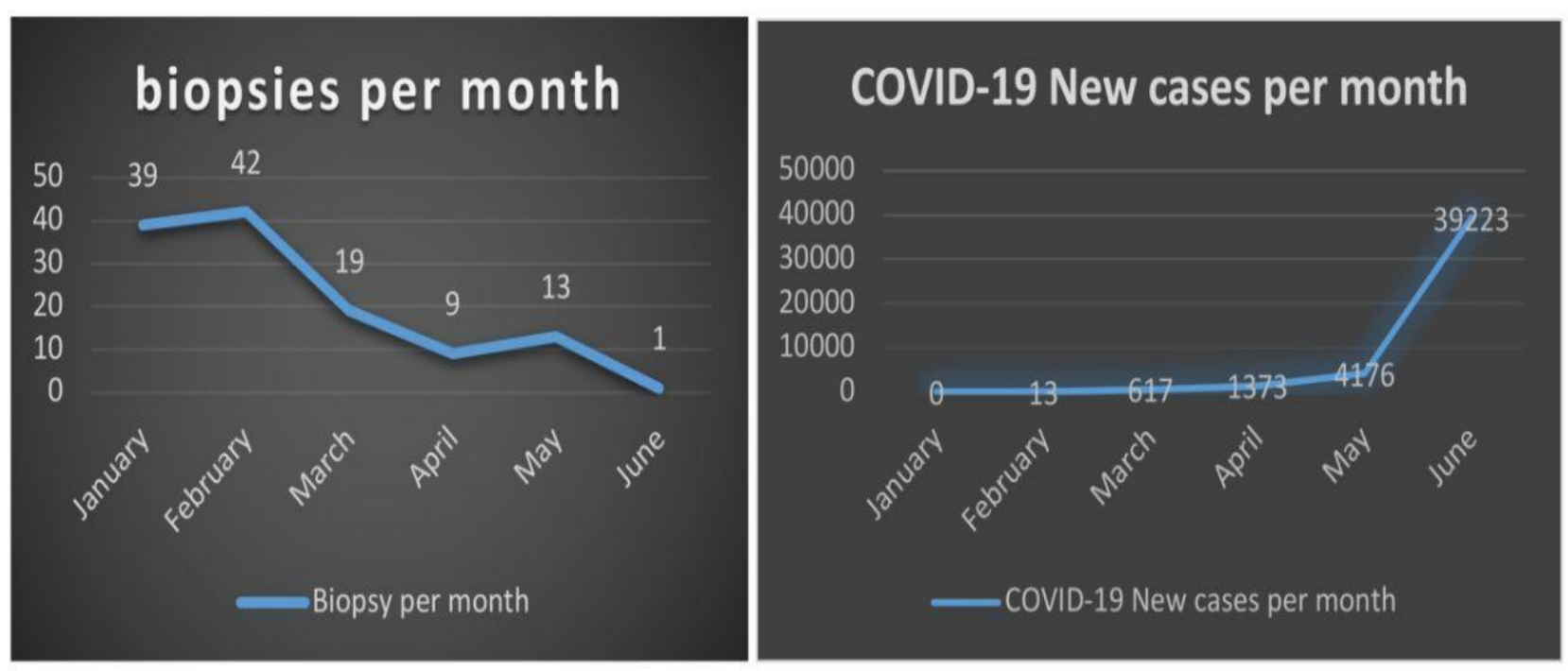

\section{Figure 5: COVID-19 and surgical dermatology}

A dramatic decrease in the number of skin biopsies at Baghdad Teaching Hospital in response to the increasing numbers of COVID-19 patients.

\section{Working on frontlines}

Baghdad has been hit particularly hard by COVID-19, where almost half of the confirmed cases were recorded. The dermatology staff felt the call of duty and were actively involved in the respiratory triage at the emergency department, where they continued to help patients and support their fellow physicians.

Nineteen percent of the dermatologists surveyed reported working in the respiratory triage or other COVID-19 related units. 


\section{Conclusion}

The COVID-19 related preventive measures are associated with an upsurge in

occupational skin diseases related to excessive handwashing, overuse of

disinfectants, and prolonged utilization of personal protective equipment. The

pandemic's psychological impact, the fear of attending hospitals, and the

shortage of medications have led to an increase in the relapse rate of common

chronic skin diseases like psoriasis and atopic dermatitis. The dermatologic

management plans were overshadowed by the current public health crisis, where

dermatologists continued to collaborate with their physician fellows in the battle

against COVID-19 infection. 


\section{Figure legends:}

\section{Figure 1: COVID-19 related cutaneous manifestations}

(A) The approximate frequency of diagnosed COVID-19 related skin manifestations reported by dermatologists. (B) 25 years old male with erythematous maculopapular eruption involving the extremities (C) 12 years old girl with generalized urticarial eruption.

Figure 2: COVID-19 pre-examination triage steps

Flowchart represents the pre-examination triage to decrease the risk of infection spread while attending the dermatology clinic and utilizing teledermatology for initial +/- follow-up assessment.

Figure 3: Hygiene-related hand dermatitis

(A) (B) Eczematous contact dermatitis (C) Papular contact dermatitis (D) Postinflammatory hyperpigmentation following severe disinfectants-related dermatitis

Figure 4: Spectrum of PPE-related dermatosis among healthcare provides working in COVID-19 era

(A) Pressure marks and frictional acne (B) Mask-induced contact dermatitis (C) and (D) Folliculitis and herpes simplex reactivation triggered by surgical mask friction (E) and (F) gown-related contact dermatitis and urticaria (G) Pressure injuries and nonspecific rash $(\mathrm{H})$ mask-related frictional acne (I) Goggles-related nasal bridge dermatitis and hyperpigmentation.

Figure 5: COVID-19 and surgical dermatology

A dramatic decrease in the number of skin biopsies at Baghdad Teaching Hospital in response to the increasing numbers of COVID-19 patients. 
medRxiv preprint doi: https://doi.org/10.1101/2020.07.26.20156380; this version posted November 28, 2020. The copyright holder for this preprint (which was not certified by peer review) is the author/funder, who has granted medRxiv a license to display the preprint in perpetuity. All rights reserved. No reuse allowed without permission.

\section{Acknowledgement}

Dr. Jhan Adwer Darzi edited our presentation, and Dr. Mohammad Fawzi Al Sultan assisted in the data collection. 


\section{References}

1- Bi Q, Wu Y, Mei S, Ye C, Zou X, Zhang Z, Liu X, Wei L, Truelove SA, Zhang T, Gao

W. Epidemiology and transmission of COVID-19 in 391 cases and 1286 of their

close contacts in Shenzhen, China: a retrospective cohort study. Lancet Infect Dis.

2020 Aug;20(8):876-877. doi: 10.1016/S1473-3099(20)30287-5

2- Guan WJ, Ni ZY, Hu Y, Liang WH, Ou CQ, He JX, Liu L, Shan H, Lei CL, Hui DS, Du

B. Clinical characteristics of coronavirus disease 2019 in China. N Engl J Med. 2020

Apr 30;382(18):1708-20. doi: 10.1056/NEJMoa2002032

3- Madigan LM, Micheletti RG, Shinkai K. How Dermatologists Can Learn and

Contribute at the Leading Edge of the COVID-19 Global Pandemic. JAMA

Dermatol. 2020 Jul;156(7):733-734. doi: 10.1001/jamadermatol.2020.1438

4- Worldometer, Iraq Population (LIVE); accessed on September 6 2020. Available

from The impact of COVID - with photo - MedRx.docx

5- World Health Organization (WHO): THE GLOBAL HEALTH OBSERVATORY,

Medical doctors (per 10000 population); last updated February 122020. 
medRxiv preprint doi: https://doi.org/10.1101/2020.07.26.20156380; this version posted November 28, 2020. The copyright holder for this

Accessed on September 7 2020. Available from:

https://www.who.int/data/gho/data/indicators/indicatordetails/GHO/medicaldoc

$\underline{\text { tors-(per-10-000-population) }}$

6- Ministry of Health of Iraq, The Daily COVID-19 Update. Accessed on September

6 2020. Available from "The daily epidemiological situation of registered

infections of the emerging coronavirus in Iraq".

7- Bai Y, Yao L, Wei T, Tian F, Jin DY, Chen L, Wang M. Presumed asymptomatic

carrier transmission of COVID-19. JAMA. 2020 Apr 14;323(14):1406-7. doi:

\section{$\underline{10.1001 / j a m a .2020 .2565}$}

8- Zhang H, Long H, Ma L, Wang G, Mu QR, Ran YP, Liu QZ, Xiao SX, Zhang XJ,

Zhang JZ, Zhang FR. Consensus on pre-examination and triage in clinic of

dermatology during outbreak of COVID-19 from Chinese experts. Int J Dermatol

Venereol. 2020 Jun;3(2):65-67. doi: 10.1097/JD9.0000000000000084

9- Hu K, Fan J, Li X, Gou X, Li X, Zhou X. The adverse skin reactions of health care

workers using personal protective equipment for COVID-19. Medicine. 2020 Jun

12;99(24):e20603. doi: 10.1097/MD.0000000000020603 
10- Smith DR, Wei N, Zhao L, Wang RS. Hand dermatitis among nurses in a newly developing region of Mainland China. Int. J. Nurs. Stud . 2005 Jan 1;42(1):13-19.

doi: 10.1016/j.ijnurstu.2004.05.007

11- Kampf G, Loeffler H. Prevention of irritant contact dermatitis among health care workers by using evidence-based hand hygiene practices: a review. Ind Health. 2007;45(5):645-652. doi: 10.2486/indhealth.45.645

12- Gefen A, Ousey K. Update to device-related pressure ulcers: SECURE prevention. COVID-19, face masks and skin damage. J Wound Care . 2020 May 2;29(5):245-59. doi: 10.12968/jowc.2020.29.5.245

13- Foo CC, Goon AT, Leow YH, Goh CL. Adverse skin reactions to personal protective equipment against severe acute respiratory syndrome-a descriptive study in Singapore. Contact Dermatitis. 2006 Nov;55(5):291-4. doi:

\section{$\underline{10.1111 / j .1600-0536.2006 .00953 . x}$}

14- Bhoyrul B, Lecamwasam K, Wilkinson M, Latheef F, Stocks SJ, Agius R, Carder

M. A review of non-glove personal protective equipment-related occupational 
dermatoses reported to EPIDERM between 1993 and 2013. Contact Dermatitis.

2019 Apr;80(4):217-221. doi: 10.1111/cod.13177

15- Zhou NY, Yang L, Dong LY, Li Y, An XJ, Yang J, Yang L, Huang CZ, Tao J.

Prevention and Treatment of Skin Damage Caused by Personal Protective

Equipment: Experience of the First-Line Clinicians Treating 2019-nCoV Infection.

Int J Dermatol Venereol. 2020 Apr 13;3(2):70-75.

doi: $10.1097 / J D 9.0000000000000085$

16- Gheisari M, Araghi F, Moravvej H, Tabary M, Dadkhahfar S. Skin Reactions to

Non-glove Personal Protective Equipment: An Emerging Issue in the COVID-19

Pandemic. J Am Acad Dermatol. 2020 Apr 17;34(7):e297-e298.

doi:10.1111/jdv.16492

17- Darlenski R, Tsankov N. Covid-19 pandemic and the skin-What should

dermatologists know?. Clinics in Dermatology. Published online 2020 Mar 24.

doi:10.1016/j.clindermatol.2020.03.012

18- Rosenbaum L. The untold toll-the pandemic's effects on patients without 
medRxiv preprint doi: https://doi.org/10.1101/2020.07.26.20156380; this version posted November 28, 2020. The copyright holder for this preprint (which was not certified by peer review) is the author/funder, who has granted medRxiv a license to display the preprint in perpetuity. All rights reserved. No reuse allowed without permission.

Covid-19. N Engl J Med. 2020 Jun 11; 382:2368-2371. doi:10.1056/NEJMms2009984

19- UNICEF Iraq, UNICEF and WHO sound the alarm on the health dangers of children in Iraq missing routine immunization during the Covid-19 pandemic; 26 April 2020. Available from:

https://www.unicef.org/iraq/press-releases/unicef-and-who\%C2\%AOsoundalarm\%C2\%A0health-dangers-children-iraq-missing-routine

20- Conforti C, Giuffrida R, Dianzani C, Di Meo N, Zalaudek I. COVID-19 and psoriasis: is it time to limit treatment with immunosuppressants? A call for action.

Dermatol Ther. 2020 Mar 11;33(4): e13298. doi: 10.1111/dth.13298

21- Shah P, Zampella JG. Use of systemic immunomodulatory therapies during the coronavirus disease 2019 (COVID-19) pandemic. J Am Acad Dermatol. 2020 Jun 1;82(6):e203-204. doi: 10.1016/j.jaad.2020.03.056

22- American Academy of Dermatology (AAD). Guidance on the use of biologic agents during COVID-19 outbreak, 18 March, 2020. Available from: https://assets.ctfassets.net/1ny4yoiyrqia/PicgNuD0lpYd9MSOwab47/023ce3cf6e 
medRxiv preprint doi: https://doi.org/10.1101/2020.07.26.20156380; this version posted November 28, 2020. The copyright holder for this preprint (which was not certified by peer review) is the author/funder, who has granted medRxiv a license to display the preprint in perpetuity. All rights reserved. No reuse allowed without permission.

\section{$\underline{\text { b82cb304b4ad4a8ef50d56/Biologics and COVID-19.pdf }}$}

23- Brownstone ND, Thibodeaux QG, Reddy VD, Myers BA, Chan SY, Bhutani T,

Liao W. Novel coronavirus disease (COVID-19) and biologic therapy in psoriasis:

infection risk and patient counseling in uncertain times. Dermatol Ther. $2020 \mathrm{Apr}$

16;10(3):1-11. doi: 10.1007/s13555-020-00377-9

24- Der Sarkissian SA, Kim L, Veness M, Yiasemides E, Sebaratnam DF.

Recommendations on dermatologic surgery during the COVID-19 pandemic. J Am

Acad Dermatol. 2020 Jul 1;83(1):e29-30. doi: 10.1016/i.jaad.2020.04.034 